\title{
The Relationship Between Urban Design and Urban Quality of Life: "A Case Study of Kastamonu City- Turkey"
}

\section{Sevgi ÖZTÜRK, Zeynep Pınar GENÇ}

Kastamonu Üniversitesi, Mühendislik ve Mimarlık Fakültesi, Peyzaj Mimarlığı Bölümü, Kastamonu

\section{Article Info:}

Research article

Corresponding author: Sevgi ÖZTÜRK e-mail: sozturk@kastamonu.edu.tr

doi: http://dx.doi.org/10.17474/acuofd.36085

\section{ABSTRACT}

The physical, social, and economic components of urban areas determine the characteristics and eligibility of urban life. Urban areas are negatively affected by rapid population growth, unplanned city development, insufficient physical environments, and social, economic and cultural problems. Nowadays, urban planning and design studies are being implemented to find solutions for the cities that lost their identities, became similar to each other, and externalized. These studies organize the physical components of the urban areas and aim to create livable and functional cities. In this study, the relationship between urban design and urban quality of life objectives is investigated in the city of Kastamonu. In this context, a poll was conducted among Kastamonu University students. As a result, it was found that there is a positively high degree (R: 0,776) linear correlation between urban design and quality of life. Moreover, it was observed that different age and gender groups have a different view of the city according to their spatial experiences.

Key Words: Urban design, urban quality, Kastamonu

\section{Kentsel Tasarım ve Kentsel Yaşam Kalitesi Arasındaki İlişki “Türkiye-Kastamonu Kenti'nden Bir Çalışma"}

\author{
Eser Bilgisi: \\ Araştırma makalesi \\ Sorumlu yazar: Sevgi ÖZTÜRK, e-mail:sozturk@kastamonu.edu.tr
}

\section{ÖZET}

Kentsel alanlar hızlı nüfus artısı, plansız yerleşme, fiziksel çevrenin ihtiyaçlara cevap verememesi, beklentilerin değişmesi, sosyal, ekonomik ve kültürel sorunların artması gibi pek çok nedenden olumsuz yönde etkilenmektedir. Günümüzde kimliksizleşmiş, dışsallaşmış ve birbirine benzeyen kent alanlarında bu sorunlara çözüm aracı olarak kentsel planlama ve tasarım çalışmaları yapılmaktadır. Bu çalışmalar, kenti oluşturan fiziksel öğeler arasındaki düzenlemeleri sağlamakta ve etkileyici, yaşanabilir, fonksiyonel kentler yaratmayı hedeflemektedir. Çalışmada, kentsel tasarım hedefleri ile kentsel yaşam kalitesi kriterleri arasındaki ilişki irdelenmeye çalışılmış ve Kastamonu Üniversitesi öğrencileri ile yapılan anket çalışması sonucunda kentsel tasarım kriterleri ile kentsel yaşam kalitesi arasında pozitif yönde yüksek derecede (R: 0,776) doğrusal bir korelasyon olduğu bulunmuştur. Bunun yanında öğrencilerin mekana dair deneyimlerine göre mekanın kullanıcı zihninde oluşan imgelerinin farklı yaş ve cinsiyet gruplarına göre farklılık gösterdiği sonucu ortaya çıkmıştır.

Anahtar Kelimeler: Kentsel tasarım, yaşam kalitesi, Kastamonu 


\section{INTRODUCTION}

Urban planning and design is targeted at increasing urban standards and raising the quality of life of individuals. However, it is known that the concept of quality of life has very comprehensive meanings beyond spatial standard measures. It is necessary to emphasize on which points those meanings should coincide with urban planning and design studies. It is considered that the role of urban studies in the basic happiness of individuals and sustaining a healthy life in all means shall be better understood in this manner. In this context, it is necessary to look through the concepts of urban planning and design and quality of life more deeply.

\section{Urban Planning and Design: As an Effective Tool of The Welfare State}

Problems including poverty, starvation, epidemic diseases, crimes, and accommodation arose in Europe following the Industrial Revolution in line with the increasing population in cities. The phenomenon of "social state" or "welfare state" that developed for improvement of those negativities targets at increasing the life welfare of individuals by providing rights including social safety, employment, just income distribution, housing, health, and education. Comprehensive planning studies were also brought into the agenda together with the targets of improving spatial problems, regulation spaceindividual relation, remedying accommodation, safety and health problems, and increasing the life standards of individuals. Planning studies gained a multi-dimensional structure in line with the changes that occurred in social and economic structures and they began to be assessed as the most rational tool to be used in terms of the sustainability of our future.
Today the phenomenon of the city, which covers all aspects of the dimension of "life" in addition to the meanings other than human-space, has been transformed into an economic struggle field. Depending on this, a fast population movement from the rural areas to the city is experienced in line with the attracting power of the cities. According to a research performed by the European Environment Agency, 70\% of the European population lived in cities and this proportion will increase (European Environment Agency, 2009). Another research indicates that urban populations constitute more than $95 \%$ of Belgium (according to 2010 census), approximately $80 \%$ of countries including Netherlands, France, Denmark, Great Britain (according to 2011 census), and approximately $71 \%$ of Turkey (CIA, 2013). The negativities arising from unplanned urbanization in spatial terms, in line with new populations added from the rural area to urban areas, support that transportation, accommodation, energy, and environmental pollution cause the unfit development of cities. At that point, urban planning, considered as a tool of finding a solution to all of those negativities experienced in the entire world, is dealt as an integrity of social, economic, ecologic, and spatial applications, which would increase the social welfare and standard of life for humans as well as providing sustainability.

Urban design is encountered as a discipline that deals with the arrangement of physical space as an interface of planning and architecture based on planning principles (Rahmatabadi, Zamankhani and Yazdani, 2011). The first examples of urban design applications can essentially be assessed as spatial applications performed at the exit point of planning phenomenon. Those applications may be interpreted as merging public areas composed of urban parks, boulevards, and 
public buildings in line with the development of landscape architecture by examining the studies performed in the USA in 19th and 20th centuries (Ersoy 2012).

In its most general meaning, it can be said that urban design covers physical studies performed on legibility of the city or city part by analyzing the image created in the users perceptions. (Lynch, 2012). However, today, this scope has expanded within the economic, social, and political relations network of the city and began to deal with creating, renewal, reproduction, and management of environments structured as an understanding for the needs of humans and sensitive to their conditions (Madanipour 1996).

\section{From Urban Standard Measures to Urban Quality Of Life}

Urban standards can be defined as the amounts of fundamental infrastructure services including water, sewerage systems, electricity, as well as the urban components including education, health, green areas, and public areas per capita measured with $\mathrm{m} 2$. Planning studies are performed considering these standard measures and it is said that the quality of life of city dwellers increases as those standards are met. However, it is known that the meaning of quality of life in urban areas expands in parallel to the changing life conditions. Quality of life plays an important role in various dimensions of planning but it is suggested that this is a complex role (Dissart and Deller, 2000). Quality of life is defined as a common component of personal development, social development, physical environment, health, safety, natural resources, and benefits and services as well (Kamp et al., 2003). It is known that quality of life differs from one society to the other and from one culture to the other and it can be said that this difference may be revealed by measuring how fundamental factors (health, sports, education, shopping, transportation and culture services, and housing and safety etc.) are perceived by the relevant society (Kabaday1 2006).

In essence, quality of life is perceived as two-dimensional. The first of these dimensions is internal (subjective) psychological mechanisms, which enable the individual to be content with his /her life, and the other is the external (objective) conditions that trigger internal mechanisms (Tekeli et.al. 2004). Unless objective factors are transformed into subjective factors, life quality remains fixed or diminishes depending on perception (Türksever 2001). For example, while factors including income level, life conditions, employment status (European Environment Agency, 2009), health, education, and recreational opportunities (Martins and Marques, nd.) cover measurable objective values, the degree to which the person may define himself/herself within those values and find pleasure in life covers the subjective dimension of the concept of life quality (Güler Üçer 2009).

Accordingly, it would not be correct to talk about the existence of the quality of urban life in any case that the users of a city, the urban infrastructure, and service areas of which are saturated in terms of urban standard measures are not content with those standards. In this case, the necessity to deal with the qualities of service areas and places as a significant issue within the context of the quality of life of the users is revealed. In other words, it is necessary to create a city structure in conformity with reliable, qualified, and social structure(s) in order to provide quality urban life. For this reason, the hypothesis that there is a significant relationship between urban 
design principles that target a readable, perceivable, healthy city structure in the axis of users and quality of urban life made up the fundamental structure of the study.

\section{MATERIAL AND METHOD}

The study is targeted at examining public areas and a busy city center based on urban design objectives and revealing the relationship established with the quality of urban life.

The study was performed in the city of Kastamonu, located in West Black Sea Region of Turkey. The city was developed along the stream of Karaçomak, which is the tributary of River Gökırmak. The first settlements were positioned in the east and west of this stream. The population has increased in recent years with the effect of the university established in the city center as well (the population of the city in 2012 was 96.217) and led to the development of the city in northerly and southerly (Öztürk and Özdemir 2013).

The city center of Kastamonu was selected as the research base since its urban image was found to be worth researching for reasons including integration of the city center with the historical fabric and the intense togetherness of public areas in the center and trade areas. It was desired to reveal the relationship between this image and the quality of life.

\section{Literature Review}

In order to determine the scope of the study, a literature review was first performed and the essays, theses, and journals related to the concepts of urban planning and design and the quality of urban life were examined.

\section{Field Research}

Significant public areas, trade areas, and transportation connections used by people frequently in the city center of Kastamonu are indicated in Figure 1. Areas, which are spatially close to one another and positioned along an axis of approximately $800 \mathrm{~m}$, were examined with a questionnaire study in terms of urban design integrity and the quality of urban life measures provided by those areas.

The questionnaire was applied to 127 persons between the ages of 18-31, composed of students of Kastamonu University, in the departments of Tourism and Hotel Management, Forest Engineering, and Landscape Architecture. It is known that among these students, the students of the Department of Landscape Architecture were 1st grade students who came to Kastamonu for the first time and the students of other departments were composed of mixed (1st, 2nd, 3rd and 4th grade) students. The survey questions were prepared considering "urban design objectives" and "quality of life objectives" for Kastamonu city center. The survey study is composed of three sections. In the first section, the personal information of students, including their department, ages, and gender were examined. In the second section, urban design objectives, in the third section quality of life objectives were examined. 

Turkey"

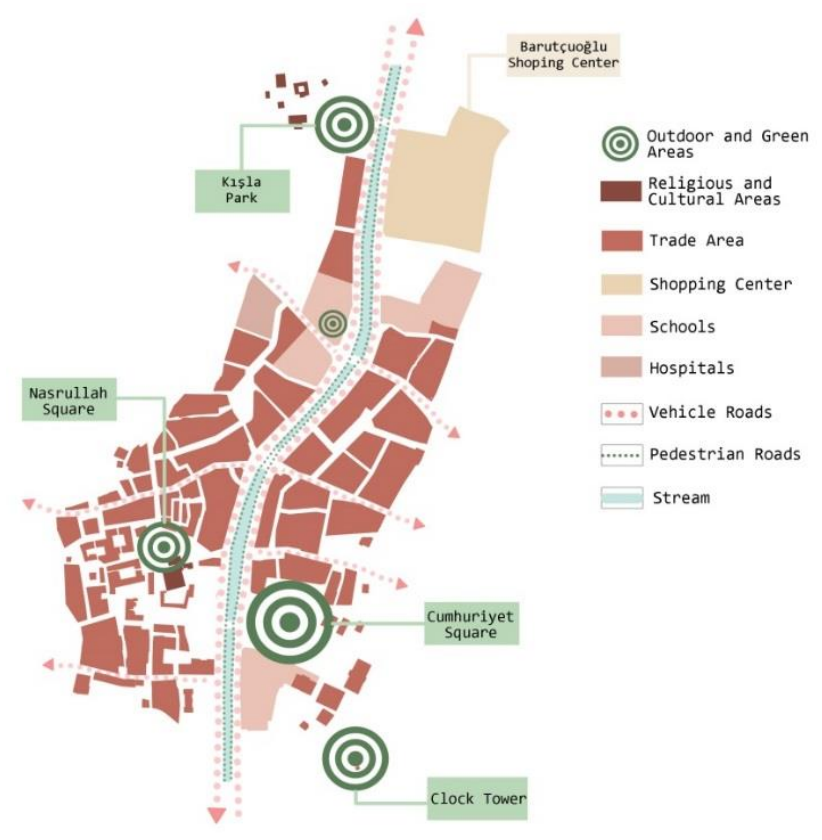

Figure 1. Study Field and Significant Usage Areas

In order to enable them to answer the questions about the spatial status related to urban design, the students were not shown any visual expression of the places named in Figure 1, including any maps or photographs. The students were requested to make an assessment according to the monitoring that remained in their perceptions concerning the integrity of those places. The reason for this is the desire to examine the situation remaining in the perception with regard to each question and not to direct the spatial considerations of the users with regard to the area. Furthermore, determining the environmental images of users in the current analysis of the place is a frequently used method in urban design studies. Image studies that define the borders, focal points, triangulation points of the place that Kevin Lynch (2012) determines according to the perceptions of users in this context have been identical with urban design studies. Although no such image mapping was performed in this study, it can be said that the purpose of the questions asked on the targets determined is to measure the city image of those who participated in the survey. At that point, one should say that urban design is approached as a fact reflected from the minds of individuals beyond looking through urban design as a spatial arrangement tool. The questions asked in the study were developed through examining the previously performed studies. Urban design objectives comprise the criteria desired to be achieved with urban design. Those criteria try to analyze the relation established with structures and other urban components (London Canada, 2010; CABE and DETR 2001, DETR 2000).

The objectives of the quality of urban life are composed of assessments of objective and subjective parameters of the concept of quality of life (UCSUR, 2012; OECD, 2011; Anderson et al. 2012). Those targets were created by examining the parameters measured and researched by many institutions. 
Survey questions were prepared on a 5 point Likert scale. Accordingly, the respondents were requested to answer 9 and 13 questions, respectively related to urban design objectives and urban quality of life objectives considering the following scale: 5: I definitely agree, 4: I agree, 3: I partially agree, 2: I disagree, 1: I definitely disagree. The obtained data was assessed with the SPSS 20.0 program. The differences between parameters were revealed in the assessment using One Way Variance Analysis. The relationship between urban design criteria and urban life quality was tested using correlation analysis. In the last section, the obtained data was assessed and suggestions were made in regards to place planning and design that would increase quality of life in Kastamonu.

\section{FINDINGS}

It is observed, in the literature studies performed, that there is a relationship between the concepts of urban planning, urban design, and quality of life. It is observed that the improvements made in the physical place through urban design or the positive image created by any place in the minds of users in terms of urban design can achieve physical, social, and psychological targets of the quality of urban life.

The survey study performed was developed from this point of view and various findings were reached. The perceptions of students on urban design and urban life criteria were assessed based on their department, gender, and ages. The assessment measures and averages of those targets were given in Table 1 .

Table 1. Assessment of urban design and quality of life objectives

\begin{tabular}{|c|c|c|c|c|}
\hline \multicolumn{3}{|r|}{ Criteria } & $\begin{array}{c}\text { Mean } \\
\text { Value }\end{array}$ & Measures \\
\hline \multirow{9}{*}{ 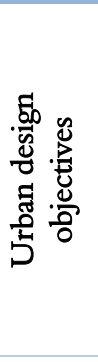 } & \multicolumn{2}{|c|}{ Character } & 2.70 & I Agree \\
\hline & \multicolumn{2}{|c|}{ Continuity and Closeness } & 2.61 & I Agree \\
\hline & \multirow{3}{*}{$\begin{array}{l}\text { Public Area } \\
\text { Quality }\end{array}$} & Safety & 2.69 & I Agree \\
\hline & & Impressiveness & 2.62 & I Agree \\
\hline & & Functionality & 2.65 & I Agree \\
\hline & \multicolumn{2}{|c|}{ Ease of Movement } & 2.29 & I Partially Agree \\
\hline & \multicolumn{2}{|l|}{ Legibility } & 3.29 & I Agree \\
\hline & \multicolumn{2}{|l|}{ Adaptability } & 2.57 & I Agree \\
\hline & \multicolumn{2}{|c|}{ Diversity/Difference } & 2.17 & I Partially Agree \\
\hline \multirow{13}{*}{ 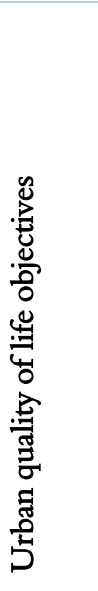 } & \multirow[t]{5}{*}{ Physical } & Green area existence & 2.39 & I Partially Agree \\
\hline & & Cleanness & 2.80 & I Agree \\
\hline & & Physical quality of eating and drinking areas & 2.40 & I Partially Agree \\
\hline & & Physical quality of resting areas & 2.45 & I Partially Agree \\
\hline & & Conformity and sufficiency of urban equipments & 2.26 & I Partially Agree \\
\hline & \multirow[t]{4}{*}{ Social } & Existence of recreational usage areas & 1.91 & I Partially Agree \\
\hline & & $\begin{array}{l}\text { Sufficiency of eating and drinking areas in social } \\
\text { terms }\end{array}$ & 2.57 & I Agree \\
\hline & & Sufficiency of resting areas in social terms & 2.29 & I Partially Agree \\
\hline & & Sufficiency of public places in social terms & 2.39 & I Partially Agree \\
\hline & \multirow[t]{4}{*}{ Psychological } & $\begin{array}{l}\text { Level of satisfaction provided by the area to the } \\
\text { user }\end{array}$ & 2.49 & I Partially Agree \\
\hline & & Level of happiness provided by the area to the user & 2.60 & I Agree \\
\hline & & Safety feeling created by the area in the user & 2.90 & I Agree \\
\hline & & Level of effect of the area on user health & 2.45 & I Partially Agree \\
\hline
\end{tabular}


Accordingly "legibility", one of the criteria regarding urban design objectives, was assessed with the value of 3.29 as the best positive consideration. One may understand on the basis of this that usage areas in the city center of Kastamonu could be found by the users easily in terms of human and vehicle mobility and that users did not have any difficulty in this area when determining their directions. The legibility measure in urban design studies is one of the most significant targets in the integration of place parts. The fact that usage areas in the Kastamonu city center have legibility, expresses the existence of a spatial integrity. Nevertheless, "diversity/difference" was found to be the most negative consideration with the value of 2.17 . It may be concluded that meeting the urban requirements and the study field was not very sufficient in terms of socio-cultural places.

The measure of safety evoked in the user by the area, one of the psychological targets of life quality, was the most negative consideration with the value of 2.90. Considering that this survey was applied particularly on a group that contains 1st grade students who came to Kastamonu from other cities, one may consider that feeling of safety about the city is a positive assessment. Nevertheless, the measure of existence of recreational areas, one of the social targets, was the most negative consideration with the value of 2.19. The fact that this consideration was a parallel value to the measure of diversity/difference, one of the urban design objectives indicates that the study field needs recreational differences and diversity.

In addition to this, examining Table 1 , it is generally found that the users expressed positive opinions on the character, continuity and closeness, quality and legibility of the area in terms of urban design, that they had partially positive considerations on ease of movement and diversity. It is observed that objectives of quality of life were achieved in terms of cleanness, and sufficiency of eating and drinking areas, happiness and safety measures in social terms but they were partially achieved in the measures of green area, quality of eating and drinking areas in physical terms, sufficiency of recreation, resting and public places, area satisfaction, and health in social terms. It is observed that eating and drinking areas were sufficient averagely in social terms but those existing areas are partially sufficient in regards to physical quality. This offers both a positive and a negative assessment for the quality of life. It is observed that the existing areas are partially sufficient in social and physical terms. It can be said that those data may shed light on potential physical studies that may be performed for this field in terms of raising the quality of urban life and realizing urban design objectives.

In addition to all of these, comparing urban design and quality of life targets, it is observed as a consequence of the data obtained in the study that there is a strong linear relation $(\mathrm{P}<0.05, \mathrm{R}: 0.776)$ in a positive direction between the criteria of urban design and the quality of life. This analysis, that confirms the hypothesis of the study, suggests that urban planning and design targets and criteria of quality of life support each other positively.

No significant meaning was found between the sections regarding urban design objectives given in Table 2 . This situation caused the departments of students to be unable to respond in conformity with the missions they will undertake and caused the answers to be similar to one another for this reason. 
"Legibility" and "diversity/difference", two of urban design objectives, were found to be significantly meaningful according to gender $(\mathrm{P}<0.05)$. Women found the city more readable with the value of 3.69 than the male participants did. The measure of "continuity and closeness" was found to be significantly meaningful according to age distribution. Students between the ages of 25-31 stated that they disagreed with the value of 1.40 and participants between the ages of 18-24 stated that they agreed with the value of 2.66. Considering that the time passed by the students older than 25 who participated in the survey in Kastamonu was longer than the time passed by the 1st grade students, it is supposed that city images may be more dominant and that they may assess this measure more rationally. In other words, the experiences of the 1st grade students on Kastamonu are limited. Furthermore, the fact that the higher the age, the more intense the relations of humans with the place, may sometimes be caused by the requirement to need more open and regular areas in the city in terms of continuity and closeness.

Table 2. Assessment of urban design objectives in terms of various characteristics of participants

\begin{tabular}{|c|c|c|c|c|c|c|c|c|c|c|}
\hline & & \multirow{3}{*}{ 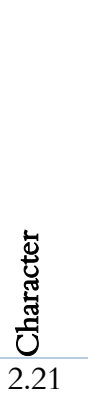 } & \multirow{3}{*}{ 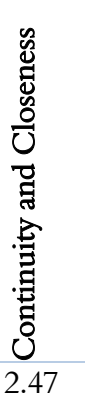 } & \multicolumn{3}{|c|}{ 弟总离 } & \multirow{3}{*}{ 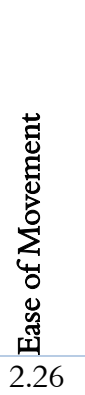 } & \multirow{3}{*}{ 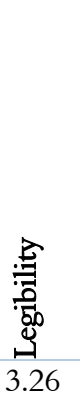 } & \multirow{3}{*}{ 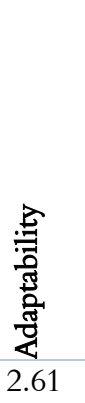 } & \multirow{3}{*}{ 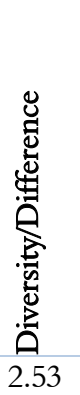 } \\
\hline & & & & 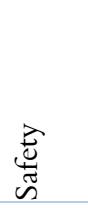 & 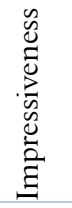 & 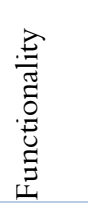 & & & & \\
\hline \multirow{4}{*}{ 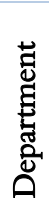 } & Tourism & & & 2.84 & 2.53 & 2.45 & & & & \\
\hline & Landscape Architecture & 2.68 & 2.41 & 2.38 & 2.27 & 2.73 & 2.22 & 3.24 & 2.32 & 1.86 \\
\hline & Forest Eng. & 3.08 & 2.85 & 2.79 & 2.94 & 2.73 & 2.37 & 3.35 & 2.71 & 2.12 \\
\hline & Significance & 0.09 & 0.215 & 0.229 & 0.07 & 0.484 & 0.881 & 0.941 & 0.398 & 0.54 \\
\hline \multirow{3}{*}{ 离 } & Male & 2.51 & 2.62 & 2.7 & 2.58 & 2.51 & 2.14 & 2.96 & 2.49 & 2.13 \\
\hline & Female & 2.91 & 2.59 & 2.67 & 2.67 & 2.81 & 2.47 & 3.69 & 2.66 & 2.69 \\
\hline & Significance & 0.096 & 0.873 & 0.92 & 0.93 & 0.159 & 0.208 & 0.005 & 0.497 & 0.031 \\
\hline \multirow{3}{*}{ 品 } & $18-24$ & 2.73 & 2.66 & 2.73 & 2.71 & 2.67 & 2.36 & 3.32 & 2.59 & 2.47 \\
\hline & $25-31$ & 2.80 & 1.40 & 2.00 & 1.80 & 2.40 & 1.60 & 2.8 & 2.4 & 1.80 \\
\hline & Significance & 0.907 & 0.034 & 0,215 & 0.15 & 0.624 & 0.24 & 0.44 & 0.758 & 0.31 \\
\hline
\end{tabular}

${ }^{\star} \mathrm{p}<0.001$ very significant; ${ }^{\star} \mathrm{p}<0.05$ significant; N.S. not significant

In Table 3, the consideration of students "with regard to physical quality of eating and drinking areas" among the criteria related to quality of life were found to be more meaningful than the other sections. Students of the Department of Landscape Architecture gave the most negative consideration. It may be interpreted that the eating and drinking areas located in the study field were not sufficient for 1st grade landscape architecture students. The reason for this could be the fact that their experiences/images with regard to the place are weaker. 
The Relationship Between Urban Design and Urban Quality of Life: "A Case Study of Kastamonu CityTurkey"

Table 3. Assessment of quality of life targets in terms of various characteristics of participants

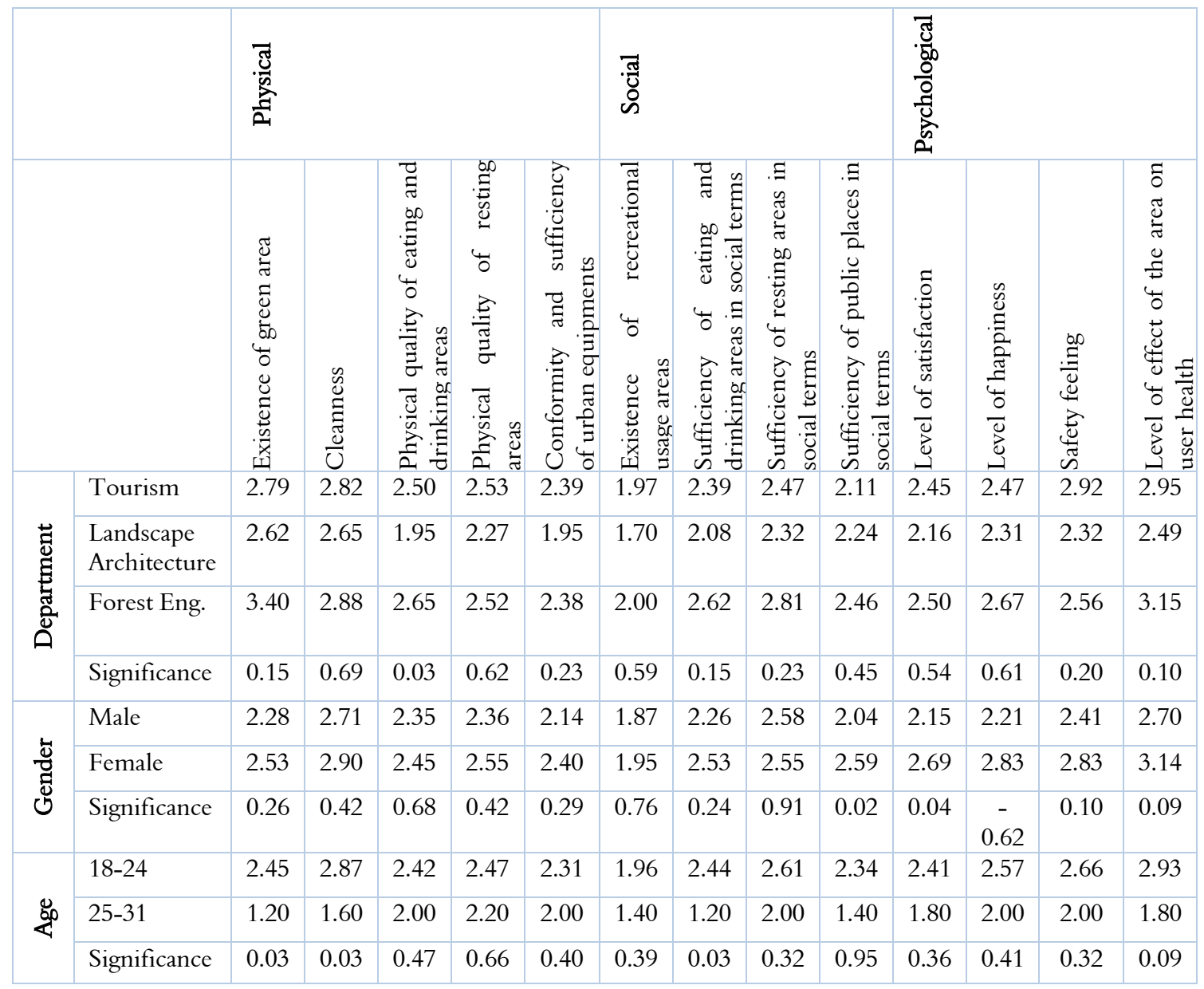

${ }^{\star \star} \mathrm{p}<0.001$ very significant; ${ }^{\star \star} \mathrm{p}<0.05$ significant; N.S. not significant

The consideration on "sufficiency of public places in social terms" and "satisfaction offered by the area to the user" was found to be significantly meaningful according to gender. Although positive answers were given by the two groups for both measures, male participants have a more negative consideration in those measures compared to the women. Although the province of Kastamonu had the most significant two squares (Nasrullah Square and Cumhuriyet Square), which we encounter as public areas within the borders of the region selected as the study field, park areas (Barracks Park,Cevizli Park) and resting areas (Clock Tower), it is found that these areas were found more insufficient by the male participants and it may be concluded that men use public areas more frequently and need those areas more. When the measure of satisfaction is examined, it is found out that both groups did not have any negative considerations with regard to the area but again, male users are partially content.

"Green area existence" in the city, "cleanness of the city" and "sufficiency of eating and drinking areas in social terms" was found to be significantly meaningful according to age distribution. In all three, criteria participants between the ages of 25-31 were convinced that those considerations were less sufficient. In the 
study performed in 2013 on outdoor and green area size in the city of Kastamonu, it was detected that the amount of outdoor and green area per capita was $1.04 \mathrm{~m} 2 / \mathrm{man}$ (Öztürk and Özdemir 2013). Green areas have a significant position in balancing the corrupted relation between humans and nature and improvement of urban life conditions. This proportion, which is too low for the city center, was assessed by students between the ages of 25-31 negatively with the value of 1.20 .

\section{DISCUSSION and CONCLUSION}

Urban design covers arrangement and improvement of the physical environment based on human focused requests and requirements. For this reason, the thoughts of users about the place in urban design studies and the expressions that the place creates in their minds are quite significant. The definition of "place" in the memories of an individual's direct urban design studies in determination of the components of the place and situation of those components.

It may also be said that urban design is an arrangement that assists the individual with meeting many of its social and spatial needs he/she has in the environment he/she lives in, besides the arrangement of the physical environment where the human lives in. Based on this fact, one may conclude that urban design has a structure that could meet a significant portion of the objective dimensions of quality of life.

In the field study performed, it was revealed that there is a strong connection between urban design objectives and the quality of life objectives. Considering the potential studies that may be performed in the future with regard to the field or the urban design projects, paying significance to eating and drinking, resting, recreational and public places in terms of quality and quantity, increasing the accessibility and usage diversity/difference of the area should be among fundamental targets according to the results of the survey. Existence of thousands of buildings resembling one another, which is not only the problem for Kastamonu but also a problem of many medium sized cities and wrong creation of city identity, leads to the occurrence of a diversity/difference criterion as a negative consideration. In addition to this, those results reveal the fact that local administrations neglected facilities that could create the opportunity of recreational activity. Outdoor and green areas in the city are found to be clean and well-kept but their spatial sizes are required to be increased. It is considered that the value of the area in terms of urban design shall increase and shall provide positive contributions to the quality of urban life when those targets assessed negatively according to survey results are fulfilled.

It is considered that the survey group who came to the city of Kastamonu from different cultures and different regions for the purpose of university education and who will forward their experiences and satisfactions about this city to other regions increased the significance of the study. Particularly, the answers given by the 1st grade students in this group who are the youngest and who are considered to know the city of Kastamonu, indicate that there is a straight proportion with place experiences of individuals in creating a city image. It was found out that those participants had more positive opinions in their relations with their surroundings. The fact that a partially negative opinion occurred in other age groups reminds that new investigations could be performed on the relationship between experience and image. It is considered that a future study which will investigate the answers to be 
given to the same questions by same 1st grade students after they experience the city for a longer time. In other words, when the 1st grade students come to 4th grade, a study can be conducted in order to make judgments on experience and image relation.

A very comprehensive criteria of quality of life, physical, social and psychological criteria, and urban design criteria were made use of in the study. This sort of study is used as a significant tool in the stages of increasing user consciousness, having users participate in urban decisions, determining the perceptions of users with regard to the environment, development of the characteristics of the existing life space, and the quality of the arrangements to be performed newly. The positive relation suggested in the study means that the satisfaction of people with the city they live in would be increased through a proper urban planning and design study. So requests, expectations, and brief participation of people become significant at the stage of urban planning and design. Criterion of participation of people, one of the components of quality of life, becomes significant for satisfaction. Support of subjective criteria by objective criteria is a significant phenomenon for a happy society and a healthy city. Good architecture, accessible places, arranged public areas, and togetherness of these functionally affect the use of the city place by people without any problem and assists with making the individuals happy in the place they live in.

\section{REFERENCES}

CABE and DETR (2000) The value of urban design. (cited 2013 Nov) http://www.designcouncil.org.uk/Documents/ Documents/Publications/CABE/the-value-ofurban-design.pdf.

CIA (2013) Urbanization, The World Factbook. (cited $2013 \quad$ Nov 24 ) https://www.cia.gov/library/publications/theworld-factbook/fields/2212.html.

DETR (2000) By design- urban design in the planning system: towards better practice. (cited 2013 Apr 4)

https:/www.gov.uk/government/uploads/syste m/uploads/attachment_data/file/7665/158490.p df.

Dissart JC, Deler SC (2000) Quality of life in the planning literature. Journal of Planning Literature. 15 (1):135-161.

Ersoy M (2012) Kapsaml planlama kavramının tarihsel gelişimi ve bugünü. (Historical Development and Present of the Concept of Comprehensive Planning) in Ersoy, M. (ed.) Kentsel planlama kuramları (Urban Planning Theories) İmge Book Store, Ankara: 120- 121.

Anderson R, Dubois H, Leoncikas T, Sandor E (2012) 3rd quality of life survey- quality of life in europe: impacts of the crisis. (cited 2013 Nov 30)

http:/www.eurofound.europa.eu/pubdocs/2012/64/ en/1/EF1264EN.pdf.

European Environment Agency (2009) Ensuring quality of life in Europe's cities and towns: Tackling the environmental challenges driven by European and global change. Copenhagen. EEA Report.

Güler Üçer ZA (2009) Kentsel yaşam kalitesinin belediye hizmetleri kapsamında belirlenmesine ve geliştirilmesine yönelik bir yaklaşım: orta ölçekli kent örnekleri. Ph.D Thesis, Gazi University FBE, Ankara.

Kabadayı H (2006) Yaşam kalitesi ve kullanıcı memnuniyetinin kentsel tasarımdaki etkisine çok boyutlu yaklaşım. Master Thesis. Istanbul Technical University.

Kamp Von I, Leidelmeijer K, Marsman G, Hollander de A (2003) Urban environmental quality and human well-being towards a conceptual framework and demarcation of concepts; A literature study. Landscape and Urban Planning. 65: 5-18, Elsevier Science B.V.

London Canada (2010) Illustrated urban design principles. (cited 2013 Apr 24) http://www.london.ca/Planning_and_Develop ment/Land_Use_Planning/Urban_Design/PD Fs/Illustrated_Urban_Design_Principles.pdf

Lynch K (2012) Kent İmajı. Türkiye İş Bankası Culture Publications, 4th Edition, Istanbul.

Madanipour A (1996) Design of urban space: An inquiry into a socio-spatial process. Chichester: John Wiley \& Sons.

Martins Marques, 2013. Evaluating quality of life in cities - towards new tools to support urban planning (cited 2013 Apr 30). 
http://www.cityfutures2009.com/PDF/55_I Martins_T_S_Marques.pdf.

OECD (2011) Compendium of OECD Well-Being Indicators. (cited 2013 Nov http://www.oecd.org/std/47917288.pdf.

Öztürk S, Özdemir Z (2013) Kentsel açı ve yeşil alanların yaşam kalitesine etkisi "Kastamonu Örneği”, Journal of Kastamonu University Faculty of Forestry, 13(1): 109- 116.

Rahmatabadi S, Zamankhani JS, Yazdani S, (2011) Urban design, socialization, and quality of life, Australian Journal of Basic and Applied Sciences, 5(12): 210-214.

Tekeli İ, Güler Ç, Vazioğlu S, Algan N, Dündar AK, (2003) Kentsel yaşam kalitesi göstergeleri: Türkiye için bir veri sistemi önerisi. Reports of Turkish Academy of Sciences no: 6, Ankara.

TÜIK (2013) Address-based population registration system (ABPRS) 2012 urban population database of the Province of Kastamonu.

Türksever NE (2001) Türkiye'de Büyüksehir alanlarında yaşam kalitesinin degerlendirilmesine yönelik bir yöntem denemesi. Ph.D Thesis. Istanbul Technical University, p. 61.

UCSUR (2012) The Pittsburg Regional Quality of life survey. (cited 2013 Apr 30) http://www.pittsburghtoday.org/specialreports /QOLreport_PT.pdf. 